\title{
Application of acute phase protein measurements in veterinary clinical chemistry
}

\author{
Henrik Hagbard PETERSEN ${ }^{\mathrm{a}, \mathrm{c} *}$, Jens Peter NIELSEN ${ }^{\mathrm{a}, \mathrm{c}}$, \\ Peter Mikael Helweg HEEGAARD ${ }^{\text {b,c }}$
}

\author{
a The Royal Veterinary and Agricultural University (RVAU), Dep. of Clinical Studies, \\ Swine Medicine, Dyrlægevej 88, DK-1870 Frederiksberg C, Denmark \\ $\mathrm{b}$ The Danish Veterinary Institute (DVI), Dep. of Immunology and Biochemistry, Bülowsvej 27, \\ DK-1790 København V, Denmark \\ ${ }^{\mathrm{c}}$ Research Centre for the Management of Animal Production and Health (CEPROS), PO Box 50, \\ DK-8830 Tjele, Denmark
}

(Received 2 May 2003; accepted 18 November 2003)

\begin{abstract}
The body's early defence in response to trauma, inflammation or infection, the acute phase response, is a complex set of systemic reactions seen shortly after exposure to a triggering event. One of the many components is an acute phase protein response in which increased hepatic synthesis leads to increased serum concentration of positive acute phase proteins. The serum concentration of these acute phase proteins returns to base levels when the triggering factor is no longer present. This paper provides a review of the acute phase proteins haptoglobin, C-reactive protein and serum amyloid A and their possible use as non-specific indicators of health in large animal veterinary medicine such as in the health status surveillance of pigs at the herd level, for the detection of mastitis in dairy cattle and for the prognosis of respiratory diseases in horses.
\end{abstract}

acute phase protein / health surveillance / mastitis / respiratory disease / haptoglobin / C-reactive protein / serum amyloid A

\section{Table of contents}

1. Introduction

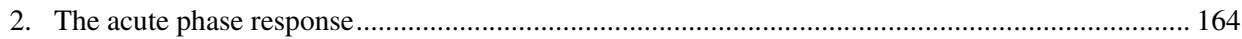

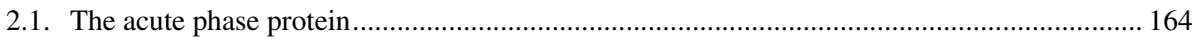

2.2. Biological function of the acute phase protein response ......................................................... 168

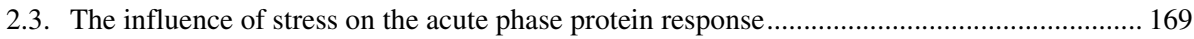

3. Selected acute phase proteins of veterinary importance ....................................................... 169

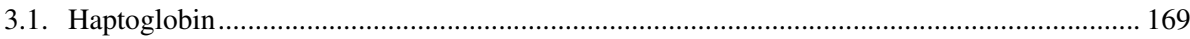

3.1.1. Biological functions of haptoglobin ...................................................................... 170

3.1.2. Factors influencing serum haptoglobin concentration ......................................... 170

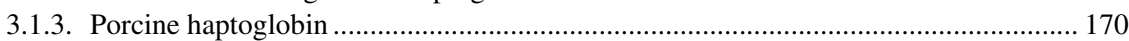

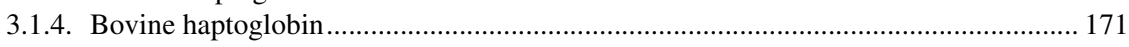

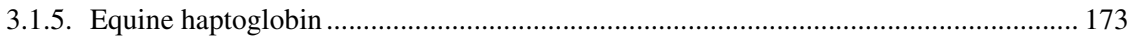

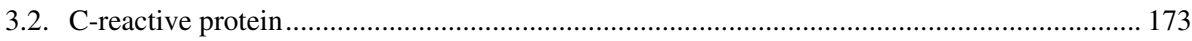

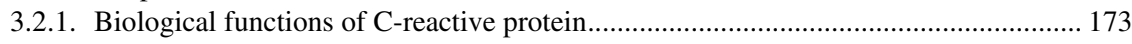

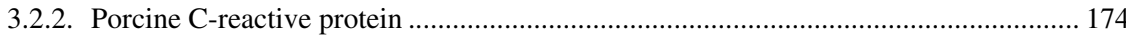

* Corresponding author: hhp@kvl.dk 


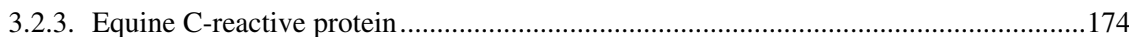

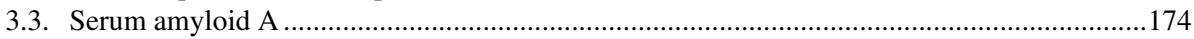

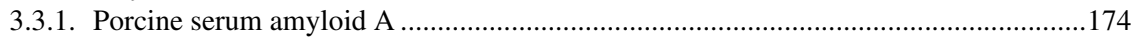

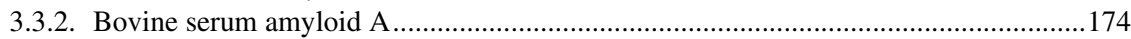

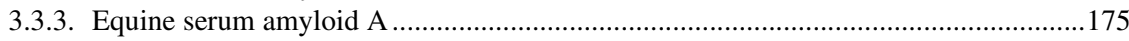

4. Application of acute phase proteins for the determination of health status

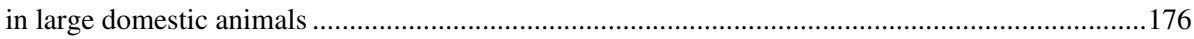

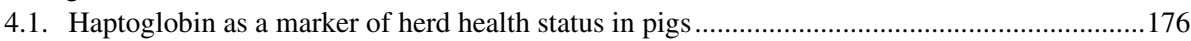

4.2. Serum amyloid $A$ and haptoglobin for the detection of bovine mastitis ..............................176

4.3. Serum amyloid $\mathrm{A}$ as the prognostic marker in equine respiratory disease .............................177

5. Conclusion.

\section{INTRODUCTION}

Animal health can be defined as the absence of disease determined by clinical examinations combined with various diagnostic tests. However, such clinical examinations may suffer from a lack of reproducibility $[11,91,132,141,174]$ and subclinical infections with an impact on animal health may remain undetected. Subclinical infections may be indirectly reflected by impaired growth performance and reproductive performance or may be diagnosed using pathology, microbiology or serology. Pathological examinations provide information on the lesions present in the individual animals at the time of death. Seropositive animals, however, may not be affected by the disease caused by the agent corresponding to the antibody $[43,179]$ and microorganisms detected in the animal may not necessarily be the cause of the disease.

It has been known for more than a century that the erythrocyte sedimentation rate is increased in stabilised blood obtained from patients with infectious diseases [19]. The rapid sedimentation rate was later found to reflect elevated concentrations of several plasma proteins, in particular the acute phase protein (APP) fibrinogen [46, 186]. The term "acute phase" was introduced in 1941 to describe serum in which another acute phase protein, the C-reactive protein, was present $[1,109]$. The acute phase response is now considered to be a dynamic process involving systemic and metabolic changes providing an early nonspecific defence mechanism against insult before specific immunity is achieved [148, 170].

\section{THE ACUTE PHASE RESPONSE}

\subsection{The acute phase protein}

The acute phase response is induced by protein hormones called cytokines acting as messengers between the local site of injury and the hepatocytes synthesising the acute phase proteins (Fig. 1). Most cytokines

Figure 1. As described in the text, type I acute phase proteins are induced by IL-1 (and TNF) while type 2 acute phase proteins are regulated by IL-6 type cytokines. A few examples of each type of acute phase protein are given in the figure (based on $[14,66,108])$ : Italics indicate biologically active substances (hormones, cytokines etc.); $\Rightarrow$ : stimulating effect on cell type/organ given; $\Rightarrow$ : inhibiting effect on cell type/organ given; $\longrightarrow$ : denotes a substance being secreted (italics) or an effect (non-italics) being caused by the given substance. $* 1$ : IL- 1 type cytokines: IL- $1 \alpha$, IL-1 $\beta$, TNF $\alpha$, TNF $\beta$ in addition to the specific IL-1 inhibitor IL-1ra, the receptors IL-1RI, IL-1RII, TNF-RI and soluble receptors. *2: IL-6 type cytokines: IL-6, oncostatin M, ciliary neutrotrophic factor, IL-11, leukemia inhibitory factor, all of which interact with receptors involving the common gp130 subunit. **Type 1 acute phase proteins are predominantly induced by IL-1 type cytokines (synergistically with IL-6), while type 2 acute phase proteins are mainly induced by IL-6 type cytokines (and can be inhibited by IL-1): AGP: $\alpha_{1}$-acid glycoprotein; C3: Complement factor C3; SAA: Serum amyloid A component; Hapto: Haptoglobin; CRP: C-reactive protein; Fib: Fibrinogen; API: $\alpha_{1}$-antitrypsin; Cerulo: Ceruloplasmin; Ra: Rat; hu: Human. 


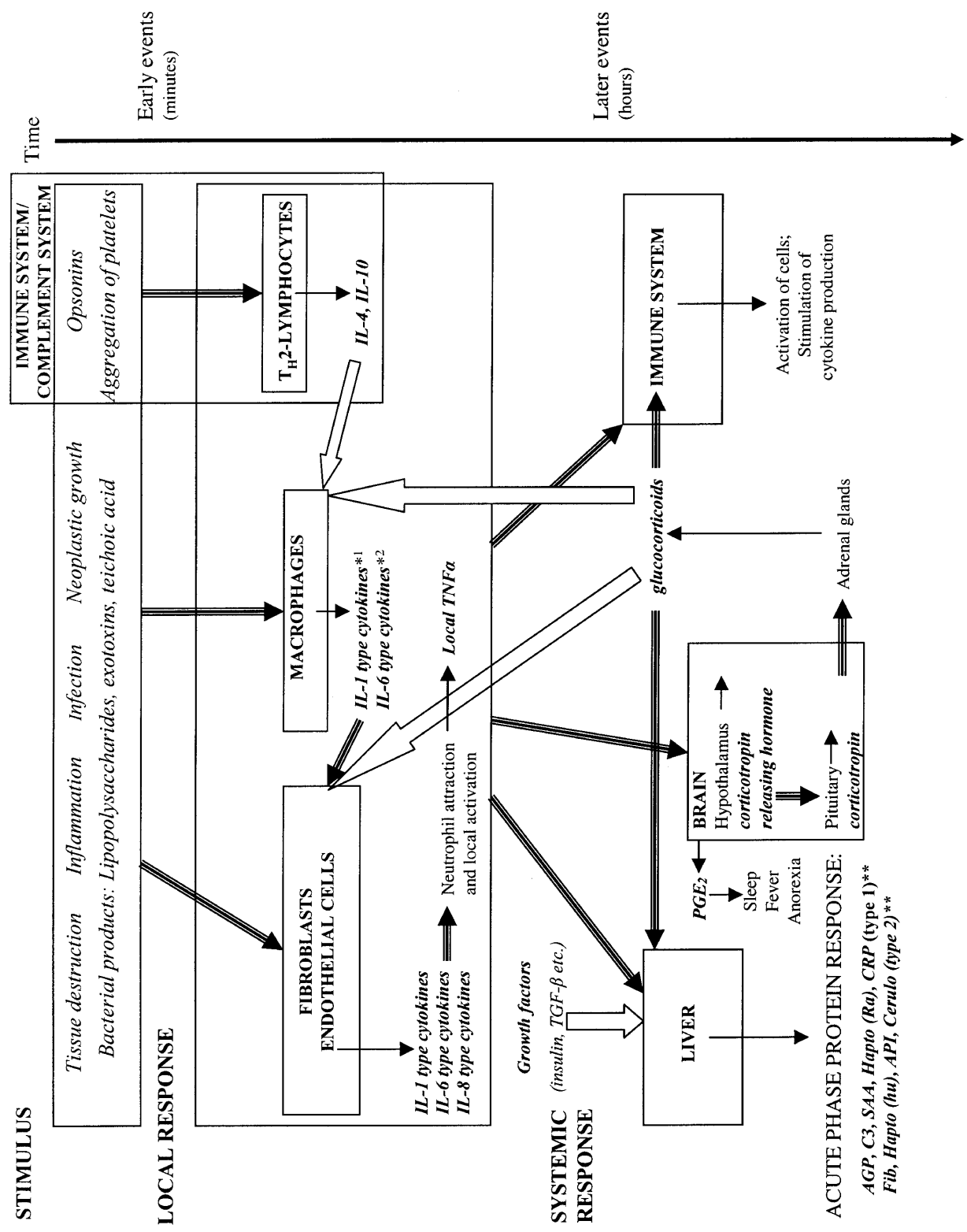


have multiple sources, multiple targets and multiple functions [55] (Tab. I) and they have been found in a large number of animal species including mammals, birds, fish, reptiles and starfish $[15,21,75,121,123$, 156]. The existence of such soluble mediators was indicated by very early experiments since it was shown that fever and fibrinogen inducing substances are present in sterile filtrates from abscesses [20,72]. These pro-inflammatory cytokines (IL-1, IL- 6 and TNF- $\alpha$ ) are secreted primarily by monocytes activated by bacterial toxins or in response to local tissue injury (Fig. 1) and are diffused into the blood stream where they can be detected in "pulses" $[60,122$, 184]. They act together through multiple, overlapping pathways and have local effects on the cells surrounding the site of injury in addition to systemic effects by transport via the blood stream to various target organs $[14,170,181]$. The serum concentration increases within a few hours after the initiating stimulus [73, 83, 184, $185]$ and they are usually cleared from the circulation within a few hours $[17,53,73$, 184].

The pro-inflammatory cytokines can be divided into two major groups with respect to acute phase protein induction, namely IL-1 type cytokines (including IL-1 and TNF- $\alpha$ ) and IL- 6 type cytokines (including IL-6) acting through different receptors located on the membrane of the hepatocytes [107, 170] (Fig. 1). IL-1 type cytokines elicit a primary autostimulatory signal $[29$, $32,127]$ stimulating the release of a secondary cytokine signal, IL-6 type cytokines, in various cell types [107]. These IL-6 type

Table I. Major biological functions of the cytokines Interleukin-1 (IL-1), Interleukin-6 (IL-6) and Tumor necrosis factor alfa (TNF- $\alpha$ ).

\begin{tabular}{lcc}
\hline Cytokine & Common Functions & Reference \\
\hline $\begin{array}{l}\text { IL-1, } \\
\text { IL-6, } \\
\text { TNF- } \alpha\end{array}$ & $\begin{array}{c}\text { Induction of hepatic acute phase response } \\
\text { Induction of fever } \\
\text { Activation of T-, B- and NK cells } \\
\text { Induction of IL-2 in T-cells }\end{array}$ & \\
\hline \multicolumn{4}{c}{ Specific functions } \\
\hline IL-1 & Activation of stroma, chondrocytes and epithelium in response to localised \\
& tissue damage & {$[122]$} \\
& Regulation of B-lymphopoiesis in bone marrow & \\
& Mediation of tissue infiltration of leucocytes (via IL-8) & {$[48]$} \\
IL-6 & Osteoblast activation, bone and cartilage degradation & {$[155]$} \\
& Participates in induction and differentiation of cytotoxic T lymphocytes & {$[131,172]$} \\
& Stimulates the differentiation of hematopoietic stem cells & {$[93]$} \\
TNF- $\alpha$ & Modulates the production of IL-1 and TNF & {$[2,157]$} \\
& Induction of IL-1 production & {$[32]$} \\
& Participates in cell destruction by suppressing protein synthesis with resulting & {$[18]$} \\
& cachexia & \\
& Elicits local endothelial damage & {$[183]$} \\
\hline
\end{tabular}


Table II. Acute phase protein reactions in different species. Peak concentration change of selected acute phase proteins during a prototype acute phase reaction (see text for references).

\begin{tabular}{lcccccccc}
\hline & Swine & Cattle & Dog & Cat & Man & Mouse & Rat & Rabbit \\
\hline Albumin & NEG & NEG & NEG & NEG? & NEG & NEG & NEG & NEG \\
Haptoglobin & III & III & II & I/II & II & III & II & III \\
$\alpha_{1}$-acid glycoprotein & 0 & II & II & II & II & II & III & II \\
Fibrinogen & I & I & II & $?$ & II & II & II & II \\
C-reactive protein & II & 0 & III & 0 & III & I & II & II \\
Serum amyloid A & III & II & III & II & III & III & 0 & III \\
Serum amyloid P & $?$ & 0 & $?$ & $?$ & 0 & I-III* & 0 & 0 \\
Major acute phase protein & III & II & $?$ & $?$ & $?$ & $?$ & II & $?$ \\
\hline
\end{tabular}

* Normal level as well as acute phase concentration changes of SAP differ strongly between different mouse strains. ?: Nothing has been reported about the reaction of the protein indicated in the literature. NEG: Decrease in concentration (10-30\%); 0: No change; I: 50\% to 100\% increase; II: Between 100\% and 10 times increase; III: More than 10 times increase.

cytokines also seem to exert a negative feed-back on the production of IL-1 type cytokines [2, 84, 115, 157].

During the acute phase response, the serum concentration of the APP changes dramatically. The APP produced by hepatocytes are present at substantially different concentrations in the blood. They can be classified according to the magnitude of their increase (positive acute phase proteins such as haptoglobin (Hp), serum amyloid A (SAA) and C-reactive protein (CRP)) or decrease (negative acute phase proteins such as albumin) in serum concentrations during an acute phase response [94, 95, 167] (Tab. II). The SAA and CRP responses are generally stronger than that of Hp [55] in the sense that the fold increase from the base line levels is higher. The base line levels of these proteins are often bordering on the unmeasurable. The concentrations reached by CRP and SAA during an acute phase response are, however, as a rule substantially lower than the acute phase concentration of haptoglobin and other acute phase proteins with non-negligible normal concentrations. The response pattern of the acute phase proteins is species specific, apart from the finding that the serum albumin concentration decreases $10-30 \%$ in all mammalian species studied [107].
Some authors have suggested a division of acute phase proteins into type 1 and type 2 acute phase proteins as indicated in Figure 1 [14]. Type 1 acute phase proteins are induced by IL-1 (and TNF- $\alpha$ ) and type 2 acute phase proteins are induced by IL- 6 and IL-6 type cytokines. A characteristic of type 1 acute phase proteins is that their synthesis is synergistically induced by IL-6, while type 2 acute phase proteins are neither induced nor synergistically stimulated by IL-1 (IL-1 is even inhibitory towards some type 2 acute phase proteins). Some examples on each type of acute phase proteins are given in Figure 1; note that species differences also exist at this level.

The serum concentration of the rapid reacting first line APP (such as SAA and CRP) increases within four hours [55, 95]. They are induced primarily by IL- 1 type cytokines and are characterised by a dramatic increase in serum concentration early after the inflammatory stimulus and a rapid normalisation. Second line acute phase proteins (such as $\mathrm{Hp}$ in most species) are induced primarily by IL- 6 type cytokines and are characterised by a later increase in serum concentration remaining elevated for up to two weeks.

The acute phase response is detectable for several days after the stimulus, but the 
Table III. Biological activities of selected acute phase proteins.

\begin{tabular}{llc}
\hline Acute phase protein & Activity & References \\
\hline Haptoglobin & Binding hemoglobin & {$[144]$} \\
& Bacteriostatic effect & {$[30,36]$} \\
& Stimulation of angiogenesis & {$[26]$} \\
& Role in lipid metabolism/development of fatty liver in cattle & {$[87,180]$} \\
& Immunomodulatory effect & {$[42,120]$} \\
& Inhibition of neutrophil respiratory burst activity & {$[129]$} \\
C-reactive protein & Complement activation and opsonisation & {$[49,116,182]$} \\
& Modulation of monocytes and macrophages, cytokine production & {$[13,25,143]$} \\
& Binding of chromatin & {$[147]$} \\
& Prevention of tissue migration of neutrophiles & {$[196]$} \\
Serum amyloid A & Transport of cholesterol from dying cells to hepatocytes & {$[102]$} \\
& Inhibitory effect on fever & {$[159]$} \\
& Inhibitory effect on the oxidative burst of neutrophilic granulocytes & {$[103]$} \\
& Inhibitory effect on in vitro immune response & {$[4,16]$} \\
& Chemotaxic effect on monocytes, polymorphonuclear & {$[9,189]$} \\
& leucocytes and T cells & \\
& Induction of calcium mobilisation by monocytes & {$[10]$} \\
& Inhibition of platelet activation & {$[195]$} \\
\hline
\end{tabular}

kinetics of the response depends on the species in question and on the extent of tissue damage $[95,108]$ (Tab. II). The maximum serum concentration of acute phase proteins is typically reached within 24 to $48 \mathrm{~h}$ after the initiation. A decline coinciding with the recovery from the infection is seen [12], and generally, feed-back regulations will limit the response leading to its resolution within four to seven days after the initial stimulus if no further stimulus occurs. Chronic inflammation (e.g. arthritis) can be perceived as a consecutive series of separate inflammatory stimuli. In such conditions, increased serum concentrations of acute phase proteins are generally observed [162]. However, the increase is lower than during acute episodes of inflammation or infection. There are also indications that the response to chronic compared to acute inflammation varies from one protein to another [74].

\subsection{Biological function of the acute phase protein response}

The acute phase response is thought to be part of a general defence-response towards tissue injury [56]. It is generally accepted that the acute phase response induced fever and slow-wave sleep is in some way beneficial to an organism under physical stress [92]. A number of the common APP (i.e. those that are acute phase proteins in most species) are likely to participate directly in the protection of the host (Tab. III). For example, Hp binds hemoglobin released by damaged erythrocytes, and, together with hemopexin and transferrin helps to alleviate the detrimental effects of free iron and to restrict the availability of free iron to invading bacteria [144]. CRP binds released bacterial or host DNA [57, 147]. For other prominent acute phase proteins like SAA, 
no biological function has yet been firmly established. Some of the common APP have recently been shown to share the ability to down-regulate pro-inflammatory cytokine production and activity in monocytic cells, potentially providing a feedback mechanism by which they affect their own induction as well as other cytokinedriven aspects of the acute phase response in vivo (reviewed by [176]). Increased expression of MHC class I related genes was demonstrated in hepatocytes after LPS treatment and this has been proposed as indicative of a possible link between innate and adaptive immunology [191].

\subsection{The influence of stress on the acute phase protein response}

In pigs, rectal temperature is known to be influenced by handling stress [169]. The effect of stress on the serum concentration of APP remains controversial, since it is difficult to distinguish the effect of stress from the effect of trauma or subclinical infections. The application of adrenocorticotrophic hormone (ACTH) or prednisolone has been shown to be followed by elevated serum concentrations of CRP [24]. Stress defined as four hours of cold, heat and transport had no effect on serum Hp concentrations in pigs [67]. Daily blood samplings for five days by jugular venipuncture revealed a low day to day variation in serum Hp concentration [138] indicating no effect of repeated daily blood samplings on Hp concentration.

In calves, stress caused by housing on a slippery floor has no effect on plasma $\mathrm{Hp}$ concentration, but plasma concentrations of SAA increase [7]. In culled cows with minor injuries, transportation does not induce an acute phase response [69]. However, in feedlot calves after transport $(1400 \mathrm{~km}$ over two days), the serum haptoglobin concentration increases [120]. A further increase was observed one day after the transport.

\section{SELECTED ACUTE PHASE PROTEINS OF VETERINARY IMPORTANCE}

Acute phase proteins may provide an alternative means of monitoring animal health. An increased focus on the application of APP for this purpose has recently been developed [164]. Due to a relatively short half life in serum and high response in diseased animals [107], APP serum responses constitute a valid measure of a systemic response to an initiating stimulus at the time of blood sampling. Like rectal temperature, APP levels are not suitable for establishing a specific diagnosis but can provide objective information about the extent of ongoing lesions in individual animals. At the herd level, APP might be useful for determining where the spread of the disease is taking place (age group, part of the production system), by providing information about the prevalence of ongoing clinical and subclinical infections indicated by the high serum concentration of selected APP [140] and by serving as a prognostic tool, with the magnitude and duration of the acute phase response reflecting the severity of infection [70, 76, 134, 164]. Important points to consider before using APP as objective and non-specific markers of animal health are the possible influence of environmental factors, handling and other types of stress in the absence of disease. In humans, a high individual variation in acute phase proteins has been observed [27, 151] and age, gender and strain specific differences in acute phase protein responses may occur in analogy with observations in laboratory rodents [136].

In this paper, we focus on haptoglobin (Hp), C-reactive protein (CRP) and serum amyloid A (SAA), which are among the strongly reacting acute phase proteins in most species (Tab. II).

\subsection{Haptoglobin}

Haptoglobin is an $\alpha_{2}$-globulin with a molecular weight of approximately $125 \mathrm{kDa}$ 
[144]. It was first described as a proteinaeous substance with the ability to increase the stability of the peroxidase activity of hemoglobin to low $\mathrm{pH}$ [142]. It has a fourchain structure, $(\alpha \beta)_{2}$, linked by disulfide bonds [144]. In humans, 16 different subtypes have been observed making $\mathrm{Hp}$ a useful genetic marker in man [175]. Porcine Hp has an electrophoretic mobility similar to that of human Hp phenotype 1-1 [106]. The molecular weight of porcine Hp has been estimated to be approximately $120 \mathrm{kDa}$ [64, 106, 161, 178]. Bovine Hp was found to consist of monomers of 16 to $23 \mathrm{kDa}$ ( $\alpha$-chains) and 35 to $40 \mathrm{kDa}$ ( $\beta$-chains) [37, $118]$ and to exist as a polymer in association with albumin with a molecular weight above $1000 \mathrm{kDa}$ in cattle serum [37]. A macromolecular protein in bovine acute phase serum with a molecular weight of 1000 to $2000 \mathrm{kDa}$ has been isolated and characterised as Hp [118]. This protein is not present in normal bovine serum. Large and heterogenous molecular sizes with different degrees of polymerisation have also been reported [119]. Equine $\mathrm{Hp}$ has been described as consisting of a pair of polypeptides with estimated molecular weights of 108 and $105 \mathrm{kDa}$, the former consisting of two identical and the latter of two different subunits [171].

\subsubsection{Biological functions of haptoglobin}

Numerous functions of haptoglobin have been proposed (Tab. III), but the primary function of $\mathrm{Hp}$ is to prevent the loss of iron by the formation of very stable complexes with free hemoglobin in the blood [5, 89, 97, 144]. Hp is thus believed to have a bacteriostatic effect by restricting the availability of iron necessary for bacterial growth [5, 23, 36]. For example, human Hp was shown to inhibit the growth of Streptococcus pyogenes in vitro [30]. Renal excretion of free hemoglobin is not seen until the total vascular binding capacity of $\mathrm{Hp}$ is saturated [97]. The haptoglobin-hemoglobin-complexes are generally believed to be routed to the liver by the reticuloendothelial system and metabolised by Kuppfer-cells [144]. In cattle, Hp has been proposed to be involved in the regulation of lipid metabolism [124] and as an immunomodulator [120]. In rats inoculated intraperitoneally with Escherichia coli lethality was decreased by simultaneous administration of Hp [36].

\subsubsection{Factors influencing serum haptoglobin concentration}

Haptoglobin is a prominent APP in most species studied (Tab. II), but the serum concentration can be influenced by other factors than the acute phase response. Increased levels of free hemoglobin in the serum are followed by decreased serum concentration of free $\mathrm{Hp}$. In cattle during an acute hemolytic crisis due to babesiosis [22] and in horses with post surgical hematomes [90], Hp disappeared from the circulation. In addition to the acute phase response, renal disease and obstructive jaundice may cause hyperhaptoglobulinemia [144]. An effect of free hemoglobin in serum samples reducing the measured concentration of $\mathrm{Hp}$ has also been found [39, 138].

\subsubsection{Porcine haptoglobin}

Haptoglobin is considered a diagnostically useful APP in most species. In newborn piglets, low plasma concentration has been observed [145]. The level of adult pigs was reached at two to three weeks of age. A peak where the concentration of haptoglobin reaches higher levels than that seen in slaughter pigs and sows was seen around 30 to 50 days of age. The $\mathrm{Hp}$ concentration was not determined after 50 days of age. Mature boars have been shown to have significantly lower Hp concentration than sows and castrated boars [145]. No effect of breed [105] but a difference between herds has been reported [62, $105,140]$. Clinical signs of lameness, respiratory disease, diarrhea, tail bite and ear necrosis was reflected in a high serum $\mathrm{Hp}$ concentration [139]. At slaughter, Hp was found to indicate lesions defined as abscesses 
and chronic abnormalities [178]. Increased $\mathrm{Hp}$ concentration follows experimentally induced inflammation $[38,96,146]$, surgery [82] as well as various experimental and natural infections (Tab. IV). It has been shown that respiratory infections caused by different serotypes of Actinobacillus pleuropneumoniae [3, 62, 64], Mycoplasma hyorhinis [110] or Porcine Reproductive and Respiratory Syndrome virus [8] are all reflected by increased haptoglobin concentration.

\subsubsection{Bovine haptoglobin}

In cattle, increased serum or plasma haptoglobin concentration was found after experimentally induced inflammation [22, 28], trauma [35, 47, 52] and also after experimental [65] and natural inflammatory diseases [6, 104] (Tab. IV). Bovine Hp was correlated to the severity of experimental infections with bovine respiratory syncytial virus [65] and spontaneous natural infections with foot-and-mouth disease virus [81]. It has also proved useful in distinguishing between acute and chronic inflammation when combined with SAA [74]. In a field study, the bovine metabolic disorders hypocalcemia and ketosis were not associated with increased $\mathrm{Hp}$ serum concentrations [164]. However, others report an association between increased serum $\mathrm{Hp}$ concentration and fatty liver (hepatic lipidosis) [87, 124, 180, 192, 193]. In experimentally induced respiratory disease caused by two separate inoculations of Bovine herpes virus 1 and Pasteurella haemolytica serotype A1, an increased Hp serum concentration was observed [58]. The increase was only found in a few animals after the first inoculation (Bovine herpes virus 1). After the second inoculation (P. haemolyt$i c a$ ) the majority of the animals responded and the concentration of $\mathrm{Hp}$ was found to correlate with fever, clinical score and weight loss [58]. In calves only infected with $P$. haemolytica serotype A1, no increase in serum $\mathrm{Hp}$ concentration was observed within the first 10 hours after inoculation [73]. The haptoglobin concentration was not determined at a later stage of the infection. This could explain the lack of haptoglobin response since a later increase might have occurred without being observed. However, a similar difference in acute phase response between calves infected with Bovine Viral Diarrhoea (BVD) virus alone and a coinfection between BVD virus and Mannheimia haemolytica has been reported [61]. The magnitude of the response was similar, but the duration was longer in the coinfection group reflecting the duration of the clinical symptoms. Recently, experimental induction of pneumonia by inoculation of $P$. multocida has shown that a high challenge volume irrespective of the number of bacteria is associated with increased plasma haptoglobin concentrations [33]. However, despite this association, a significantly higher mean post-infection $\mathrm{Hp}$ concentration was also observed when compared to the mean preinfection concentration. When applied as a predictor of subsequent clinical respiratory tract disease by screening a population of feedlot cattle at entry and at 40 and 65 days of feed, a poor predictive ability of serum Hp was reported [194]. In feedlot cattle with clinical respiratory tract disease a high but variable Hp response was observed [188]. No correlation between Hp serum concentration and rectal temperature or pathological lesions in the lungs was found, but lower serum concentration was observed in cattle treated with antibiotics.

Hp has also been associated with bacterial contamination of the uterus and delayed uterine involution [160]. However, others have reported that $\mathrm{Hp}$ concentrations remain low in acute postpartum metritis and high concentrations are seen only in cases of severe metritis [71]. In dairy cows with toxic puerperal metritis, antimicrobial therapy is associated with a decrease in serum Hp concentration [165].

Banding is not associated with changes in the Hp concentration [41], whereas castration is followed by an increased Hp level 
Table IV. Summary of treatments and infections leading to increased haptoglobin concentration.

\begin{tabular}{|c|c|c|}
\hline Animal & Cause & References \\
\hline \multirow[t]{8}{*}{ Pig } & Experimental local aseptic inflammation & {$[38,96,146]$} \\
\hline & $\begin{array}{l}\text { Intramuscular injection of lipopolysaccharide } \\
\text { (Escherichia coli serotype } 0.55: \mathrm{B} 5 \text { ) }\end{array}$ & [34] \\
\hline & Surgery & [82] \\
\hline & $\begin{array}{l}\text { Infection with Actinobacillus pleuropneumoniae } \\
\text { (serotype } 1,2 \text { and } 5 \text { ) }\end{array}$ & {$[3,62,64,99]$} \\
\hline & Infection with Mycoplasma hyorhinis & [110] \\
\hline & Infection with Toxoplasma gondii & [85] \\
\hline & $\begin{array}{l}\text { Infection with Porcine Reproductive and Respiratory Syndrome } \\
\text { (PRRS) virus }\end{array}$ & [8] \\
\hline & $\begin{array}{l}\text { Intranasal inoculation of Bordetella bronchiseptica and toxigenic } \\
\text { Pasteurella multocida type D }\end{array}$ & [54] \\
\hline \multirow[t]{21}{*}{ Cattle } & Experimental local aseptic inflammation & {$[22,28]$} \\
\hline & Infection with bovine virus diarrhea virus and Pasteurella haemolytica & [61] \\
\hline & Experimental infection with $P$. multocida & [33] \\
\hline & Experimental infection with $P$. haemolytica & [87] \\
\hline & Infection with bovine herpes virus 1 and $P$. haemolytica $\mathrm{A} 1$ & [58] \\
\hline & Experimental infection with bovine respiratory syncytial virus & [65] \\
\hline & Natural infections with foot-and-mouth disease virus & [81] \\
\hline & Mastitis & {$[40,68,70,130,152]$} \\
\hline & Various acute infections under field conditions & [164] \\
\hline & Clinical respiratory tract disease & [188] \\
\hline & Various inflammatory diseases & [6] \\
\hline & Acute inflammations & [104] \\
\hline & Castration & {$[35,47,50,51,52]$} \\
\hline & Ruminotomy & [119] \\
\hline & Metritis & {$[71,165,166]$} \\
\hline & Severe uterine bacterial post partum contamination & [160] \\
\hline & Fatty liver (hepatic lipidosis) & {$[87,124,192]$} \\
\hline & Nonfeeding for 3 days & [88] \\
\hline & Starvation for 2 days combined with Dexamethasone treatments & [193] \\
\hline & Transportation for 2 days & [120] \\
\hline & Major injuries at slaughter/culling & {$[69,149]$} \\
\hline \multirow[t]{6}{*}{ Horse } & Experimental aseptic arthritis & [80] \\
\hline & Experimental local aseptic inflammation & {$[113,171]$} \\
\hline & Experimentally induced noninfectious laminitis & [45] \\
\hline & Inhalation of Equine Influenza virus strain 2 & [90] \\
\hline & Grass sickness (Equine dysautonomia) & [114] \\
\hline & Castration & {$[90,171]$} \\
\hline
\end{tabular}


$[35,47,50,51]$. Following surgical castration of 14-month old bulls, a higher plasma $\mathrm{Hp}$ concentration has been observed when compared to banded and entire bulls [52]. A higher $\mathrm{Hp}$ serum concentration has also been reported following ruminotomy [119].

In calves to be slaughtered, haptoglobin concentration in serum indicates gross lesions at post mortem inspection [59]. The serum concentration did not correlate with the severity of the lesions observed. Higher $\mathrm{Hp}$ concentration has been reported in culled dairy cows with higher prevalence of pathological lesions as compared to steers [149]. However, the higher Hp value was attributable to a small number of animals with high concentrations. Also, in emergency slaughtered dairy cows, a higher Hp concentration was observed [69]. However, $\mathrm{Hp}$ did not quantitatively predict the meat inspection result since the correlation with the relative amount of condemned meat was poor.

\subsubsection{Equine haptoglobin}

In horses, increased Hp serum or plasma concentration has been observed following surgery $[90,171]$, experimental inflammations $[45,80,113,171]$ as well as during natural diseases [90, 114, 171] (Tab. IV). One report has shown haptoglobin to be a useful indicator of viral infection in stabled thoroughbreds [90] as the concentration increased. No such increase in equine serum Hp concentration was observed following vaccination against influenza and tetanus.

Non-infectious arthritis [80] and carbohydrate induced laminitis [45] has also been shown to induce increased concentrations of Hp. Also, in horses suffering from grass sickness (Equine dysautonomia), increased serum Hp concentration has been reported [114]. Following castration complicated by post operative scrotal infection, two peaks in serum $\mathrm{Hp}$ concentration were observed [90]. No increase was observed in horses with colic [114].

\subsection{C-reactive protein}

C-reactive protein (CRP) was discovered in the blood of patients during the acute phase of pneumococcal pneumonia [177]. CRP has a molecular size of approximately $115 \mathrm{kDa}$ and consists of five noncovalently associated polypeptide subunits [135]. In human medicine, some authors regard CRP as reliable in distinguishing viral from bacterial infections. For example, bacterial meningitis results in a significantly elevated serum concentration of CRP, whereas no changes are seen in viral meningitis [134]. The duration of the CRP response was found to reflect the clinical course of the illness. CRP is also reported to be useful for distinguishing between viral and bacterial pneumonia [111]. However, others could not distinguish between bacterial and viral infections due to a large individual variation in CRP production [151]. Also, recent research has shown that slightly elevated CRP concentration might be a valid marker for increased risk of cardiac disease in humans $[100,158]$.

\subsubsection{Biological functions of C-reactive protein}

The protein was named the C-reactive protein because of its ability to bind pneumococcal C-polysaccharide [177]. The presence of CRP has also been described in human patients during acute infections caused by acute lobar pneumonia, active rheumatic fever and bacteremia caused by "colon bacillus" [1]. Among the biological functions described in the literature are complement activation $[49,182]$ and opsonisation [116, 182] (Tab. III). During the early stages of infection, the serum concentration of CRP increases. This increase has been described to be evident before an elevated rectal temperature is observed [148]. Even though increased concentrations of bovine CRP during naturally occurring infections and a correlation with herd health status have been reported [101], CRP is generally not considered an acute phase protein in cattle [125] (Tab. II). 


\subsubsection{Porcine $C$-reactive protein}

The serum and plasma concentration of CRP increases after turpentine induced aseptic inflammation in pigs $[38,96]$ and infections with $A$. pleuropneumoniae [64, $98,99]$. Plasma concentrations of CRP correlate well to the clinical score and the effect of antibiotic treatment in experimental A. pleuropneumoniae infection in pigs $[98,99]$.

\subsubsection{Equine C-reactive protein}

Increased serum concentration of CRP has been found in horses suffering from aseptic inflammation induced by intramuscular turpentine injections [173]. Increased plasma concentration has been observed in carbohydrate induced laminitis [45]. A high serum concentration was also found in horses with pneumonia, enteritis, arthritis and after castration [173].

\subsection{Serum amyloid A}

The molecular weight of the native form of SAA is estimated to approximately $180 \mathrm{kDa}$ [135] since SAA is normally found in a complex with lipoproteins. After denaturation, the estimated weight of the subunits is between 9 and $14 \mathrm{kDa}$ in different species [77, 128, 135]. In slaughtered pigs, different isoforms of SAA have been described [178]. Three different isoforms of SAA have been described in horses [77] and two in cattle [112]. In cattle, the presence of a milk-specific form of SAA ("milk-SAA", MAA) has indicated the local synthesis of SAA in the udder induced by mastitis $[40,112]$. The function of SAA is not firmly established but several have been proposed (Tab. III).

\subsubsection{Porcine serum amyloid A}

An increased serum concentration of SAA has been observed in pigs following surgery [82] and experimental infection with A. pleuropneumoniae [64] (Tab. V). The SAA concentration has been found to reflect the clinical and post mortem findings in pigs experimentally infected with A. pleuropneumoniae [64].

\subsubsection{Bovine serum amyloid $A$}

In cattle, an increased SAA serum and plasma concentration has been found following experimentally induced $[22,28]$ and naturally occurring inflammation [6] as well as experimental and natural infections (Tab. V). The SAA response during viral respiratory diseases is well described [61, 65]. As for $\mathrm{Hp}$, the SAA response is of longer duration in coinfections with virus and bacteria when compared to pure virus infections [61]. The magnitude and the duration of the response correlated well with the severity of the clinical signs [61, 65]. After intratracheal inoculation with Pasteurella multocida the SAA concentration increased [73]. After inoculation directly into the lungs, a simultaneous increase in a $14 \mathrm{kDa}$ SAA protein and decrease in two other $(7.5-9.0 \mathrm{kDa}$ and $<6.5 \mathrm{kDa})$ SAA proteins have been reported [190] indicating that these immunologically related proteins act as positive and negative acute phase proteins.

SAA has been suggested to be more useful in distinguishing between acute and chronic inflammation than neutrophil counts and white blood cell counts [74]. When screening dairy cow herds, SAA was found to reflect systemic inflammatory disease [86]. A good agreement (i.e. high specificity) between ruling out inflammation by a clinical examination performed by field veterinarians and SAA negative serum samples was observed. However, a low sensitivity indicated discrepancies between the clinical examination diagnosing inflammation and high serum SAA concentration. According to the authors, this could be due to subclinical disease. The results could also be affected by the findings that clinical ketosis without clinical signs of inflammation also increases the SAA concentration 
Table V. Summary of treatments and infections leading to increased serum amyloid A concentration.

\begin{tabular}{llc}
\hline Animal & Cause & References \\
\hline Pig & Surgery & {$[82]$} \\
& Infection with Actinobacillus pleuropneumoniae Serotype 5 & {$[64]$} \\
Cattle & Prolonged injection of low doses of lipopolysaccharide (E. coli O111:B4) & {$[185]$} \\
& Inflammation & {$[6,86]$} \\
& Subclinical inflammation & {$[86]$} \\
& Mastitis & {$[40,70,133]$} \\
& Infection with Pasteurella haemolytica serotype 1 & {$[73]$} \\
& ([193] found decreased concentration) & {$[61]$} \\
& Experimental infection with Bovine Viral Diarrhoea Virus and/or & \\
Mannheima haemolytica & {$[65]$} \\
& Experimental infection with bovine respiratory syncytial virus & {$[88]$} \\
& Nonfeeding for 3 days & {$[79,80]$} \\
Experimental aseptic arthritis. & {$[79,137,154]$} \\
Surgical trauma & {$[128]$} \\
Hocal aseptic inflammation & {$[168]$} \\
Septicemia and focal infections in foals & {$[76]$} \\
& Various infections in foals & {$[128,154]$} \\
& Enteritis, pneumonia, diarrhea and fever & {$[137]$} \\
Experimental infection with Equine herpes virus Serotype 1 & {$[78]$} \\
\hline Infection with Equine influenza virus serotype A2 &
\end{tabular}

[86]. Also, a difference between farms has been reported since dairy cows kept and fed inside have a significantly higher SAA concentration than other cows [86].

\subsubsection{Equine serum amyloid $A$}

Equine SAA is present at trace levels only in healthy horses [79, 137] but increases rapidly following tissue injury, infection or inflammation [79]. In foals, high SAA serum concentration has been found until one to two weeks of age [128, 154]. In mares, an increased SAA concentration peaking three days after foaling was found to persist until one month post partum $[128,154]$.

Increased SAA concentration in serum has been shown to follow experimentally induced aseptic inflammation [79, 80, 128], surgical trauma $[79,137,154]$ in addition to natural infections $[76,78,79$, 168] (Tab. V). In foals with various bacterial infections, higher SAA concentration has been reported [76]. Also in foals with septicaemia and focal infections (i.e. navel infections or arthritis), high SAA concentration has been reported [168]. SAA correlates well with CRP in horses with clinical signs of inflammation [128], fever and clinical signs of respiratory disease [78]. Also enteritis and diarrhea have been reflected by high SAA concentrations [128, 154]. However, individual variations in SAA peak concentration has been described in horses subjected to the same inducing stimulus such as experimental aseptic arthritis or surgical castration [79]. 


\section{APPLICATION OF ACUTE PHASE PROTEINS FOR THE DETERMI- NATION OF HEALTH STATUS IN LARGE DOMESTIC ANIMALS}

APP might be applied as unspecific markers of clinical and subclinical infections $[63,140,148]$, to discriminate between acute and chronic disease [74] and for prognostic purposes, since the duration and magnitude of the response reflect the severity of the disease [78, 134, 164] and the effect of treatment $[76,99]$. Three different examples will be presented below.

\subsection{Haptoglobin as a marker of herd health status in pigs}

In the pig production system, health status is usually defined as freedom from disease agents countrywide (freedom of Swine Fever or Foot- and Mouth Disease) or at the farm level (Specific Pathogen Free (SPF) herds). However, the pigs might be infected with other agents leading to poor health despite high health declarations. APP testing offers a tool for assessing a health estimate that are based on the extent of inflammation and tissue damage.

An important practical aspect is the subclinical conditions that do not lead to overt disease but may cause suboptimal growth and decreased welfare. A number of investigations indicate the ability of APP measurements to reveal such conditions. For example, Canadian and American researchers showed that in immunologically naive boars moved to new facilities, an increase in haptoglobin concentration was observed before the clinical signs of the disease were evident [63]. The Hp concentration remained high, and the animals subsequently showed clinical signs of the disease (depression, respiratory distress and cyanosis). The authors suggest that higher Hp serum concentration prior to the clinical signs could be due to early, subclinical pathological conditions. Also, lower gaining pigs were found to have higher $\mathrm{Hp}$ levels than high gaining pigs [44]. The serum Hp concentration increased significantly with age in conventional slaughter pigs without clinical signs but not in slaughter pigs from high health (SPF-x) herds, indicating that subclinical disease in conventional herds may be the cause of the higher serum Hp concentration in older pigs [140]. Therefore, $\mathrm{Hp}$ seems to be a promising marker of health status by reflecting a broad spectrum of ongoing clinical as well as subclinical diseases.

\subsection{Serum amyloid $A$ and haptoglobin for the detection of bovine mastitis}

In dairy herds, mastitis is a production disease of major importance. Cows with clinical signs of mastitis are easily spotted by farmers and proper treatment can be applied. However, subclinical infections may not be observed and remain untreated. Cow-side tests, such as the California Mastitis Test, are available but laboursome and time consuming if applied to a large number of animals. For the screening of herds, the somatic cell counts (SCC) are used despite the fact that high levels do not necessarily reflect mastitis [153]. In order to detect subclinical infections, APP might be applied.

Hp serum concentration increased in experimentally induced mastitis $[68,70$, 152] and in field infections of different etiology $[40,130,164]$. In some papers, no correlation between Hp and disease severity was observed [40, 70]. Serum Hp concentration was higher in cows suffering from mastitis compared to healthy cows, but no difference was observed between the cows suffering from mild and moderate mastitis [40]. However, others consider Hp as indicating the severity of infection and predicting the fatal outcome in heifers with experimentally induced mastitis [68]. The reason for this difference remains unexplained, but the use of different infection models might be a plausible cause. The association between fatty liver (hepatic lipidosis) and increased serum Hp concentration [192, 193] might also influence on the results since the fatty liver similar to mastitis can occur in high producing dairy 
cows. Interestingly, in milk samples, higher $\mathrm{Hp}$ concentration has been found in infected quarters compared to opposite non-infected quarters and to milk from cows without mastitis [40]. The concentration in serum and milk was found to be correlated, indicating that $\mathrm{Hp}$ in milk may originate from serum.

Serum amyloid A has also been found to be a marker of experimentally induced [70, 133] and naturally occurring mastitis [40]. In experimentally induced E. coli FT238 mastitis, the serum SAA response was found to be related to the severity of infection [70]. In cows suffering from mild to moderate clinical mastitis caused by field infections of different origins, higher SAA serum concentration has been found compared to healthy cows, but no correlation between SAA and disease severity was found [40]. The concentration of SAA in milk samples increases prior to the increase in SCC in cows experimentally infected with Streptococcus uberis [133]. Similarly, in cows suffering from mastitis caused by field infections, a significantly higher SAA concentration was found in the milk from infected compared to non-infected quarters [40]. Higher SAA concentration was also found in moderately as compared to mildly infected quarters. A lack of correlation between SAA in milk and serum [40], the expression of a serum amyloid protein homologue in the mammary gland [117] and the finding of a milk specific form of bovine SAA [112] indicate that a form of SAA is produced locally in the mammary gland.

As stated above, there is evidence that clinical and subclinical mastitis can be revealed by high serum concentration of $\mathrm{Hp}$ and SAA. It is also of interest that the concentration of acute phase proteins in milk from infected quarters is higher than in noninfected quarters [40]. By testing milk, a large number of samples are easily obtained in a way that is less stressful than obtaining a blood sample. If APP are produced locally in the udder as a response to mastitis, they might be more rapid and sensitive markers of acute inflammation than the somatic cell count. However, future studies on the applicability of APP in milk as markers of mastitis are needed.

\subsection{Serum amyloid $A$ as a prognostic marker in equine respiratory disease}

Acute phase proteins reflecting subclinical infections and the severity of infection could be valuable tools for assessing individual reconvalescence periods for horses recovering from respiratory infections. SAA has been found valuable in monitoring virus infections such as influenza and rhinovirus in human medicine [126, 187]. It might also be useful in the management of bacterial and viral infections in horses by large scale monitoring in stables and as a prognostic tool in relation to clinical severity and the recovery of individual horses [78, 137].

Serum concentration of SAA has been found to increase in foals during infection with Rhodococcus equi [76], Equine influenza serotype A2 (H3N8) [78], Equine herpes virus serotype 1 and Streptococcus equi [137]. A statistically significant association between SAA serum concentration and the severity of clinical signs of respiratory disease as well as rectal temperature has been observed [78]. The serum concentration increased during the first $48 \mathrm{~h}$ in horses infected with Equine influenza virus and had returned to the base level in uncomplicated cases when tested after 11 to 22 days. High serum SAA concentrations in reconvalescent horses at day 11 to 22 were explained by secondary infections or undetected tissue damage, but this was not verified. The serum concentration of SAA remained undetectable in horses in contact with EHV-1 and S. equi without clinical signs of the disease [137].

Laboratory diagnoses of equine influenza, equine herpes virus and equine arteritis virus are usually performed by obtaining 
paired blood samples three weeks apart for the determination of antibodies. If increased titres are observed during the three weeks, the horse is likely to have contracted a viral infection. However, an increased concentration of acute phase proteins in the first blood sample would indicate acute inflammation based on one blood sample only. Though an exact diagnosis is not provided, the acute phase proteins could serve as a tool for deciding what further testings should be performed and whether the horse is fit for training. However, future studies of APP in equine medicine are needed before the applicability can be assessed.

\section{CONCLUSION}

The objective determination of animal health is important among other things due to the increasing focus of consumers, politicians and farmers on the welfare of animals. As non-specific markers of inflammation, APP testing is a tool for studying pathogenesis, the spread of infectious diseases or the efficacy of pharmaceuticals and vaccines. The measurement of acute phase proteins might also prove useful in defining the objective health status of an animal or a herd. The present definition of health as the freedom of certain specified disease agents does not guarantee healthy animals. In addition to the welfare aspect, the farmer would benefit when subclinical inflammatory infections are revealed and curative treatments performed. However, it must be stressed that acute phase proteins just like rectal temperature do not provide information on the etiology of disease and therefore must be supplemented by diagnostic tests if curative treatments are to be performed. Also, the APP production can be affected by other parameters than the acute phase response. For example, in human medicine hypohaptoglobulinemia is seen in patients with liver impairment as severe liver damage reduces the hepatic capacity for acute phase protein synthesis [144]. This must be considered when using APP as a measure of the acute phase reaction.

We have here discussed acute phase proteins and their possible use as markers of pig health at the herd level, for the detection of bovine mastitis and as a prognostic marker for equine respiratory infections. However, an international standardisation of acute phase protein assays is needed before they can be applied for the systematic health monitoring in veterinary medicine. This work was performed [163] as a part of the European Concerted Action on Animal Acute Phase Protein Standards supported by the EC and pig aspects are currently being studied in an EC Shared Cost Project (Acute Phase Proteins in Pig Production).

\section{ACKNOWLEDGEMENTS}

We thank Associate Professor Susanne Nautrup Olsen for feed back on the paper and DVM Lars Holst Pedersen for providing information on his present work with SAA in experimental Streptococcus uberis mastitis.

\section{REFERENCES}

[1] Abernethy T.J., Avery O.T., The occurrence during acute infections of a protein not normally present in the blood. 1 . Distribution of the reactive protein in patients sera and the effect of calcium on the flocculation reaction with C polysaccharide of Pneumococcus, J. Exp. Med. 73 (1941) 173-182.

[2] Aderka D., Junming L., Vilcek J., IL-6 inhibits lipopolysaccharide-induced tumor necrosis factor production in cultured human monocytes, U937 cells, and in mice, J. Immunol. 143 (1989) 3517-3523.

[3] Agers $\emptyset$ H., Friis C., Nielsen J.P., Penetration of amoxycillin to the respiratory tract tissues and secretions in Actinobacillus pleuropneumoniae infected pigs, Res. Vet. Sci. 64 (1998) 251-257.

[4] Aldo-Benson M., Benson M.D., SAA suppression of immune response in vitro: Evidence for an effect on $\mathrm{T}$ cell-macrophage interaction, J. Immunol. 128 (1982) 23902392. 
[5] Allison A.C., Symposium on haemoglobin, 51, The Royal Society of Medicine, London, England, 1958, pp. 641-645.

[6] Alsemgeest S.P.M., Kalsbeek H.C., Wensing T., Koeman J.P., van Ederen A.M., Gruys E., Concentrations of serum amyloid A (SAA) and haptoglobin (hp) as parameters of inflammatory diseases in cattle, Vet. Q. 16 (1994) 21-23.

[7] Alsemgeest S.P.M., Lambooy I.E., Wierenga H.K., Dieleman S.J., Meerkerk B., van Ederen A.M., Niewold T.A., Influence of physical stress on the plasma concentration of serumamyloid A (SAA) and haptoglobin $(\mathrm{Hp})$ in calves, Vet. Q. 17 (1995) 9-12.

[8] Asai T., Mori M., Okada M., Uruno K., Yazava S., Shibata I., Elevated serum haptoglobin in pigs infected with porcine reproductive and respiratory syndrome virus, Vet. Immunol. Immunopathol. 70 (1999) 143148.

[9] Badolato R., Wang J.M., Murphy W.J., Lloyd A.R., Michiel D.F., Bausserman L.L., Kelvin D.J., Oppenheim J.J., Serum amyloid $\mathrm{A}$ is a chemoattractant: Induction of migration, adhesion and tissue infiltration of monocytes and polymorphonuclear leucocytes, J. Exp. Med. 180 (1994) 203-209.

[10] Badolato R., Johnston J.A., Wang J.M., McVicar D., Xu L.L., Oppenheim J.J., Kelvin D.J., Serum amyloid A induces calcium mobilisation and chemotaxis in human monocytes by activating a pertussis toxinsensitive signalling pathway, J. Immunol. 155 (1995) 4004-4010.

[11] Bailey S.M., Sarmandal P., Grant J.M., A comparison of three methods for assessing inter-observer variation applied to measurement of the symphysis-fundal height, $\mathrm{Br}$. J. Obstet. Gynaecol. 96 (1989) 1266-1271.

[12] Ballou S.P., Kushner I., C-reactive protein and the acute phase response, Adv. Intern. Med. 37 (1992) 313-336.

[13] Ballou S.P., Lozanski G., Induction of inflammatory cytokine release from cultured human monocytes by C-reactive protein, Cytokine 4 (1992) 361-368.

[14] Baumann H., Gauldie J., The acute phase response, Immunol. Today 15 (1994) 74-80.

[15] Beck G., Habicht G.S., Isolation and characterisation of a primitive interleukin-1 like protein from an invertebrate, Asterias forbesi, Proc. Natl. Acad. Sci. USA 83 (1986) 7429 7433.

[16] Benson M.D., Aldo-Benson M., Effect of purified protein SAA on immune responses in vitro: Mechanisms of suppression, $\mathrm{J}$. Immunol. 122 (1979) 2077-2082.
[17] Beutler B.A., Milsark I.W., Cerami A., Cachectin/Tumor Necrosis Factor: production, distribution and metabolic fate in vivo, J. Immunol. 135 (1985) 3972-3977.

[18] Beutler B.A., Milsark I.W., Cerami A.C., Passive immunization against cachectin/tumor necrosis factor protects mice from lethal effect of endotoxin, Science 229 (1985) 869-871.

[19] Biernaki E., Uber die Beziehungdes Plasms zu den rothen Blutkörperchen und über den Wert verschiedener Methoden der Blutkörperchenvolumbestimmung, Z. Phys. Chem. 19 (1894) 179-224.

[20] Billroth T., Die Allgemeine chirurgische Pathologie und Therapie, Reimer, Berlin, 1875.

[21] Bird S., Wang T., Zou J., Cunningham C., Secombes C.J., The first cytokine sequence within cartilaginous fish: IL- $1 \beta$ in the small spotted catshark (Scyliorhinus canicula), J. Immunol. 168 (2002) 3329-3340.

[22] Bremner K.C., Studies on haptoglobin and haemopexin in the plasma of cattle, Aust. J. Exp. Biol. Med. Sci. 42 (1964) 643-656.

[23] Bullen J.J., The significance of iron in infection, Rev. Infect. Dis. 3 (1981) 1127-1138.

[24] Bürger W., Ewald C., Fennert E.-M., Increase in $\mathrm{C}$-reactive protein in the serum of piglets (pCRP) following ACTH or corticosteroid administration, J. Vet. Med. Ser. B 45 (1998) $1-6$.

[25] Cermak J., Key N.S., Bach R.R., Balla J., Jacob H.S., Vercellotti G.M., C-reactive protein induces human periferal blood monocytes to synthesize tissue factor, Blood 82 (1993) 513-520.

[26] Cid M.C., Grant D.S., Hoffmann G.S. Auerbach R., Fauci A.S., Kleinman H.K., Identification of haptoglobin as an angiogenic factor in sera from patients with systemic vasculitis, J. Clin. Investig. 91 (1993) 977-985.

[27] Clark G.R., Fraser C.G., Biological variation of acute phase proteins, Ann. Clin. Biochem. 30 (1993) 373-376.

[28] Conner J.G., Eckersall P.D., Bovine acute phase response following turpentine injection, Res. Vet. Sci. 44 (1988) 82-88.

[29] Content J., De Wit L., Poupart P., Odenakker G., Van Damme J., Billiau A., Induction of a 26-kDa-protein mRNA in human cells treated with an interleukin-1-related, leucocyte-derived factor, Eur. J. Biochem. 152 (1985) 253-257.

[30] Delange J., Langlois M., Ouyang J., Claeys G., De Buyzere M., Wuyts B., Effect of haptoglobin phenotypes on growth of Streptococcus pyogenes, Clin. Chem. Lab. Med. 36 (1998) 691-696. 
[31] Dinarello C.A., Interleukin-1 and the pathogenesis of the acute-phase response, N. Engl. J. Med. 311 (1984) 1413-1418.

[32] Dinarello C.A., Cannon J.G., Wolff S.M., Bernheim H.A., Beutler B., Cerami A., Figari I.S., Palladino A., O'Connor J.V., Tumor Necrosis Factor (Cachectin) is an endogenous pyrogen and induces production of Interleukin 1, J. Exp. Med. 163 (1986) 14331450

[33] Dowling A., Hodgson J.C., Schock A., Donachie W., Eckersall P.D., McKendrick I.J., Experimental induction of pneumonic pasteurellosis in calves by intratracheal infection with Pasteurella multocida biotype A:3, Res. Vet. Sci. 73 (2002) 37-44.

[34] Dritz S.S., Owen K.Q., Goodband R.D., Nelssen J.L., Tokach M.D., Chengappa M.M., Blecha F., Influence of lipopolysaccharide-induced immune challenge and diet complexity on growth performance and acute-phase protein production in seggregated early-weaned pigs, J. Anim. Sci. 74 (1996) 1620-1628.

[35] Earley B., Crowe M.A., Effects of ketoprofen alone or in combination with local anesthesia during the castration of bull calves on plasma cortisol, immunological and inflammatory responses, J. Anim. Sci. 80 (2002) 10441052.

[36] Eaton J.W., Brandt P., Mahoney J.R., Haptoglobin: A natural bacteriostat, Science 215 (1982) 691-693.

[37] Eckersall P.D., Conner J.G., Plasma haptoglobin in cattle (Bos taurus) exists as polymers in association with albumin, Comp. Biochem. Physiol. B 96 (1990) 309-314.

[38] Eckersall P.D., Saini P.K., McComb C., The acute phase response of acid soluble glycoprotein, alpha-1-acid glycoprotein, ceruloplasmin, haptoglobin and C-reactive protein, in the pig, Vet. Immunol. Immunopathol. 51 (1996) 377-385.

[39] Eckersall P.D., Duthie S., Safi S., Moffat D., Horagoda N.U., Doyle S., Parton R., Bennett D., Fitzpatrick J.L., An automated biochemical assay for haptoglobin: Prevention of interference from albumin, Comp. Haematol. Int. 9 (1999) 117-124.

[40] Eckersall P.D., Young F.J., McComb C. Hogarth C.J., Safi S., Weber A., McDonald T., Nolan A.M., Fitzpatrick J.L., Acute phase proteins in serum and milk from dairy cows with clinical mastitis, Vet. Rec. 148 (2001) $35-41$.

[41] Eicher S.D., Dailey J.W., Indicators of acute pain and fly avoidance behaviors in Holstein calves following tail-docking, J. Dairy Sci. 85 (2002) 2850-2858

[42] El Ghmati S.M., Van Hoeyveld E.M., Van Strijp J.A.G., Ceuppens J.L., Stevens E.A.M., Identification of haptoglobin as an alternative ligand for CD11b/CD18, J. Immunol. 156 (1996) 2542-2552.

[43] Elbers A.R.W., Tielen M.J.M., Cromwijk W.A.J., Hunneman W.A., Varition in seropositivity for some respiratory disease agents in finishing pigs: epidemiological studies on some health parameters and farm and management conditions in the herds, Vet. Q. 14 (1992) 8-13.

[44] Eurell T.E., Bane D.P., Hall W.F., Schaeffer D.J., Serum haptoglobin concentration as an indicator of weight gain in pigs, Can. J. Vet. Res. 56 (1992) 6-9.

[45] Fagliari J.J., McClenahan D., Evanson O.A., Weiss D.J., Changes in plasma protein concentrations in ponies with experimentally induced alimentary laminitis, Am. J. Vet. Res. 59 (1998) 1234-1237.

[46] Fahreus R., The suspension stability of the blood, Acta Med. Scand. 55 (1921) 1-228.

[47] Faulkner D.B., Eurell T., Tranquilli W.J., Ott R.T., Ohl M.W., Cmarik G.F., Zinn G., Performance and health of weanling bulls after butorphanol and xylazine administration at castration, J. Anim. Sci. 70 (1992) 2970 2974.

[48] Fauteux L.J., Osmond D.G., IL-1 as a systemic modifier of B lymphopoiesis, J. Immunol. 156 (1996) 2376-2383.

[49] Fiedel B.A., Simpson R.M., Gewurz H., Effects of C-reactive protein (CRP) on platelet function, in: Kushner I., Volankis J.E., Gewurz H. (Eds.), C-reactive protein and the plasma protein response to tissue injury, The New York Academy of Science 389, New York, 1982, pp. 263-273

[50] Fisher A.D., Crowe M.A., Ó’Nualláin E.M., Monaghan M.L., Larkin J.A., O'Kiely P., Enright W.J., Effects of cortisol on in vitro interferon-ã production, acute-phase proteins, growth and feed intake in a calf castration model, J. Anim. Sci. 75 (1997) 10411047.

[51] Fisher A.D., Crowe M.A., Ó’Nualláin E.M., Monaghan M.L., Prendiville D.J., O'Kiely P., Enright W.J., Effects of suppressing cortisol following castration of bull calves on adrenocorticotrophic hormone, in vitro interferon- $\gamma$ production, leukocytes, acute-phase proteins, growth and feed intake, J. Anim. Sci. 75 (1997) 1899-1908.

[52] Fisher A.D., Knight T.W., Cosgrove G.P., Death A.F., Anderson C.B., Duganzich D.M., 
Matthews L.R., Effects of surgical or banding castration on stress responses and behaviour of bulls, Aust. Vet. J. 79 (2001) 279-284.

[53] Fossum C., Wattrang E., Fuxler L., Jensen K.T., Wallgren P., Evaluation of various cytokines (IL- 6 , IFN- $\alpha$, IFN- $\gamma$, TNF- $\alpha$ ) as markers for acute bacterial infection in swine - a possible role for serum interleukin-6, Vet. Immunol. Immunopathol. 64 (1998) 161172.

[54] Francisco C.J., Shryock T.R., Bane D.P., Unverzagt L., Serum haptoglobin concentration in growing swine after intranasal challenge with Bordetella bronchiseptica and toxigenic Pasteurella multocida type D, Can. J. Vet. Res. 60 (1996) 222-227.

[55] Gabay C., Kushner I., Acute-phase proteins and other systemic responses to inflammation, N. Engl. J. Med. 340 (1999) 448-454.

[56] Gauldie J., Richards C., Northemann W., Fey G., Baumann H., IFN beta 2/BSF2/IL-6 is the monocyte-derived HSF that regulates receptor-specific acute phase gene regulation in hepatocytes, Ann. N.Y. Acad. Sci. 557 (1989) 46-59.

[57] Gewurz H., Mold C., Siegel J., Fiedel B., Creactive protein and the acute phase response, Adv. Intern. Med. 27 (1982) 345-372.

[58] Godson D.L., Campos M., Attah-Poku S.K., Redmond M.J., Cordeiro D.M., Sehti M.S., Harland R.J., Babiuk L.A., Serum haptoglobin as an indicator of the acute phase response in bovine respiratory disease, Vet. Immunol. Immunopathol. 51 (1996) $277-$ 292.

[59] Gray M.L., Young C., Stanker L.H., Bounous D.I., Measurement of serum haptoglobin in neonatal farm-raised and bob veal calves using two immunoassay methods, Vet. Clin. Pathol. 25 (1996) 38-42.

[60] Gruys E., Touissant M.J.M., Landman W.J.M., Tivapasi M., Chamanza R., van Veen L., Infection, inflammation and stress inhibit growth. Mechanisms and non-specific assessment of the processes by acute phase proteins, in: Wensing T. (Ed.), Production diseases in farm animals, 2, Wageningen Press, The Netherlands, 1999, pp. 72-87.

[61] Gånheim C., Hultén C., Carlsson U., Kindahl H., Niskanen R., Waller K.P., The acute phase response in calves experimentally infected with bovine viral diarrhea virus and/ or Manheimia haemolytica, J. Vet. Med. Ser. B 50 (2003) 183-190.

[62] Hall W.F., Eurell T.E., Hansen T.E., Herr W.F., Serum haptoglobin concentration in swine naturally or experimentally infected with Actinobacillus pleuropneumoniae, J.
Am. Vet. Med. Assoc. 201 (1992) 17301733.

[63] Harding J.C., Baarsch M.J., Murtaugh M.P., Association of Tumour Necrosis Factor and acute phase reactant changes with post arrival disease in swine, J. Vet. Med. Ser. B 44 (1997) 405-413.

[64] Heegaard P.M.H., Klausen J., Nielsen J.P., González-Ramón N., Piñeiro M., Lampreave F., Alava M.A., The porcine acute phase response to infection with Actinobacillus pleuropneumoniae. Haptoglobin, C-reactive protein, major acute phase protein and serum amyloid A protein are sensitive indicators of infection, Comp. Biochem. Physiol. B 119 (1998) 365-373.

[65] Heegaard P.M.H., Godson D.L., Toussaint M.J.M., Tjørnehøj K., Larsen L.E., Viuff B., Rønsholt L., The acute phase response of haptoglobin and serum amyloid A (SAA) in cattle undergoing experimental infection with bovine respiratory syncytial virus, Vet. Immunol. Immunopathol. 77 (2000) 151159.

[66] Heinrich P.C., Castell J.V., Andus T., Interleukin- 6 and the acute phase response, Biochem. J. 265 (1990) 621-636.

[67] Hicks T.A., McGlone J.J., Whisnant C.S., Kattesh H.G., Norman R.L., Behavioral, endocrine, immune and performance measures for pigs exposed to acute stress, J. Anim. Sci. 76 (1998) 474-483.

[68] Hirvonen J., Pyörälä S., Jousimies-Somer H., Acute phase response in heifers with experimentally induced mastitis, J. Dairy Res. 63 (1996) 351-360

[69] Hirvonen J., Hietakorpi S., Saloniemi H., Acute phase response in emergency slaughtered dairy cows, Meat Sci. 46 (1997) 249257.

[70] Hirvonen J., Eklund K., Teppo A.M., Huszenica G., Kulcsar M., Saloniemi H., Pyörälä S., Acute phase response in dairy cows with experimentally induced Escherichia coli mastitis, Acta Vet. Scand. 40 (1999) 35-46.

[71] Hirvonen J., Huszenicza G., Kulcsàr M., Pyörälä S., Acute-phase response in dairy cows with acute postpartum metritis, Theriogenology 51 (1999) 1071-1083.

[72] Homburger F., A plasma fibrinogen-increasing factor obtained from sterile abscesses in dogs, J. Clin. Investig. 24 (1945) 43-45.

[73] Horadagoda A., Eckersall P.D., Hodgson J.C., Gibbs H.A., Moon G.M., Immediate responses in serum TNFalfa and acute phase protein concentrations to infection with $\mathrm{Pas}$ teurella haemolytica A1 in calves, Res. Vet. Sci. 57 (1994) 129-132. 
[74] Horadagoda N.U., Knox K.M.G., Gibbs H.A., Reid S.W.J., Horagoda A., Edwards S.E.R., Eckersall P.D., Acute phase proteins in cattle: discrimination between acute and chronic inflammation, Vet. Rec. 144 (1999) 437-441.

[75] Huang H., Potter A.A., Campos M., Leighton F.A., Willson P.J., Haines D.M., Yates W.D.G., Pathogenesis of porcine Actinobacillus pleuropneumoniae, Part II: Roles of proinflammatory cytokines, Can. J. Vet. Res. 63 (1999) 69-78.

[76] Hultén C., Demmers S., Serum amyloid A (SAA) as an aid in the management of infectious disease in the foal: comparison with total leucocyte count, neutrophil count and fibrinogen, Equine Vet. J. 34 (2002) 693-698.

[77] Hultén C., Sletten K., Foyn Bruun C., Marhaug G., The acute phase serum amyloid A (SAA) in the horse: isolation and characterisation of three isoforms, Vet. Immunol. Immunopathol. 57 (1997) 215-227.

[78] Hultén C., Sandgren B., Skiöldebrand E., Klingeborn B., Marhaug G., Forsberg M., The acute phase protein serum amyloid A (SAA) as an inflammatory marker in equine Influenza Virus infection, Acta Vet. Scand. 40 (1999) 323-333.

[79] Hultén C., Tulamo R.-M., Suominen M.M., Burvall K., Marhaug G., Forsberg M., A noncompetitive chemiluminescence enzyme immunoassay for the equine acute phase protein serum amyloid A (SAA) - a clinically useful inflammatory marker in the horse, Vet. Immunol. Immunopathol. 68 (1999) 267281

[80] Hultén C., Grönlund U., Hirvonen J., Tulamo R.-M., Suominen M.M., Marhaug G., Forsberg M., Dynamics in serum of the inflammatory markers serum amyloid A (SAA), haptoglobin, fibrinogen and $\alpha 2$-globulins during induced non-infectious arthritis in the horse, Equine Vet. J., 34 (2002) 699-704.

[81] Höfner M.C., Fosbery M.W., Eckersall P.D., Donaldson A.I., Haptoglobin response of cattle infected with foot-and-mouth disease virus, Res. Vet. Sci. 57 (1994) 125-128.

[82] Jacobson M., Lindberg J.E., Lindberg R., Segerstad C.H., Wallgren P., Fellström C., Hultén C., Jensen-Waern M., Intestinal cannulation: Model for study of the midgut of the pig, Comp. Med. 51 (2001) 163-170.

[83] Jesmok G., Lindsey C., Duerr M., Fournel M., Emerson T., Efficacy of monoclonal antibody against human recombinant tumor necrosis factor in E. coli-challenged swine, Am. J. Pathol. 141 (1992) 1197-1207.
[84] Jordan M., Otterness I.G., Ng R., Gessner A., Röllinghoff M., Beuscher H.U., Neutralization of endogeneous IL-6 suppresses induction of IL-1 receptor antagonist, J. Immunol. 154 (1995) 4081-4090.

[85] Jungersen G., Jensen L., Riber U., Heegaard P.M.H., Petersen E., Poulsen J.S.D., BilleHansen V., Lind P., Pathogenicity of selected Toxoplasma gondii isolates in young pigs, Int. J. Parasitol. 29 (1999) 1307-1319.

[86] Karreman H.J., Wentink G.H., Wensing T., Using serum amyloid A to screen dairy cows for sub-clinical inflammation, Vet. Q. 22 (2000) 175-178.

[87] Katoh N., Nakagawa H., Detection of haptoglobin in the high-density lipoprotein and the very high-density lipoprotein fractions from sera of calves with experimental pneumonia and cows with naturally occurring fatty liver, J. Vet. Med. Sci. 61 (1999) 119124.

[88] Katoh N., Oikawa S., Oohashi T., Takahashi Y., Itoh F., Decreases of apolipoprotein B-100 and A-I concentrations and induction of haptoglobin and serum amyloid $\mathrm{A}$ in nonfed calves, J. Vet. Med. Sci. 64 (2002) 51-55.

[89] Keene W.R., Jandl J.H., The sites of hemoglobin catabolism, Blood 26 (1965) 705-718.

[90] Kent J.E., Goodall J., Assessment of an immunoturbidimetric method for measuring equine serum haptoglobin concentrations, Equine Vet. J. 23 (1991) 59-66.

[91] Klinkhoff A.V., Bellamy N., Bombardier C., Carette S., Chalmers A., Esdaile J.M. Goldschmidt C., Tugwell P., Smythe H.A., Buchanan W.W., An experiment in reducing interobserver variability of the examination for joint tenderness, J. Rheumatol. 15 (1988) 492-494.

[92] Kluger M.J., Ringler D.H., Anver M.R., Fever and survival, Science 188 (1975) 166168.

[93] Koike K., Nakahata T., Takagi M., Kobayashi T., Ishiguro A., Tsuji K., Naganuma K., Okano A., Akiyama Y., Akabane T., Synergism of BSF-2/Interleukin 6 and Interleukin 3 on development of multipotential hemopoietic progenitors in serum-free culture, J. Exp. Med. 168 (1988) 879-890.

[94] Kushner I., The phenomenon of the acute phase response, in: Kushner I., Volanakis J.E., Gewurz H. (Eds.), C-reactive protein and the plasma protein response to tissue injury, The New York Academy of Science 389, New York, 1982, pp. 39-48.

[95] Kushner I., Mackiewicz A., Acute phase proteins as disease markers, Dis. Markers 5 (1987) 1-11. 
[96] Lampreave F., González-Ramón N., MartínezAyensa S., Hernández M.-A., Lorenzo H.-K., García-Gil A., Piñeiro A., Characterisation of the acute phase serum protein response in pigs, Electrophoresis 15 (1994) 672-676.

[97] Laurell C.-B., Nymann M., Studies on the serum haptoglobin level in hemoglobinemiae and its influence on renal excretion of hemoglobin, Blood 12 (1957) 493-506.

[98] Lauritzen B., Lykkesfeldt J., Friis C., Evaluation of a single dose versus a divided dose regimen of Danofloxacin in treatment of Actinobacillus pleuropneumoniae infection in pigs, Res. Vet. Sci. 74 (2003) 271-277.

[99] Lauritzen B., Lykkesfeldt J., Skaanild M.T., Angen Ø., Nielsen J.P., Friis C., Putative biomarkers for evaluating antibiotic treatment: an experimental model of porcine Actinobacillus pleuropneumoniae infection, Res. Vet. Sci. 74 (2003) 261-270.

[100] Ledue T.B., Rifai N., Preanalytic and analytic sources of variations in C-reactive protein measurement: Implications for cardiovascular disease risk assessment, Clin. Chem. 49 (2003) 1258-1271.

[101] Lee W.-C., Hsiao H.C., Wu Y.-L., Lin J.-H., Lee Y.-P., Fung H.-P., Chen H.-H., Chen Y.H., Chu R.-M., Serum C-reactive protein in dairy herds, Can. J. Vet. Res. 67 (2003) 102107.

[102] Liang J., Sipe J.D., Recombinant human serum amyloid A (apoSAA $_{\mathrm{p}}$ binds cholesterol and modulates cholestrol flux, J. Lipid Res. 36 (1995) 37-46.

[103] Linke R.P., Bock V., Valet G., Rothe G., Inhibition of the oxidative burst response of $\mathrm{N}$-formyl peptide-stimulated neutrophils by serum amyloid-A protein, Biochem. Biophys. Res. Commun. 176 (1991) 11001105.

[104] Lipperheide C., Gothe C., Petersen B., Sommer H., Bestimmung von haptoglobin im plasma von Rind, Schwein und Pferd mit dem Nephelometer BN 100, Tierarztl. Umsch. 52 (1997) 420-426.

[105] Lipperheide C., Diepers N., Lampreave F., Alava M.A., Petersen B., Nephelometric determination of haptoglobin plasma concentrations in fattening pigs, J. Vet. Med. Ser. A 45 (1998) 543-550.

[106] Lockhart W.L., Chung W.P., Smith D.B., Studies on the dissociation of porcine haptoglobin, Can. J. Biochem. 50 (1972) 775781.

[107] Mackiewicz A., Acute phase proteins and transformed cells, Int. Rev. Cytol. 170 (1997) $225-300$.
[108] Mackiewicz A., Kushner I., Baumann H., Acute phase proteins molecular biology, biochemistry, and clinical applications, CRC Press, Boca Raton, 1993.

[109] MacLeod C.M., Avery O.T., The occurrence during acute infections of a protein not normally present in the blood. III. Immunological properties of the $\mathrm{C}$-reactive protein and its differentiation from normal blood proteins, J. Exp. Med. 73 (1941) 173-182.

[110] Magnusson U., Wilkie B., Artursson K., Mallard B., Interferon-alpha and haptoglobin in pigs selectively bred for high and low immune response and infected with $\mathrm{Myco}$ plasma hyorhinitis, Vet. Immunol. Immunopathol. 68 (1999) 131-137.

[111] McCarthy P.L., Frank A.L., Ablow R.C., Masters S.J., Dolan T.F., Value of C-reactive protein test in the differentiation of bacterial and viral pneumonia, J. Pediatr. 92 (1978) 454-456.

[112] McDonald T.L., Larson M.A., Mack D.R., Weber A., Elevated extrahepatic expression and secretion of mammary-associated serum amyloid A 3 (M-SAA3) into colostrum, Vet. Immunol. Immunopathol. 83 (2001) 203 211.

[113] Mills P.C., Auer D.E., Kramer H., Barry D. $\mathrm{Ng}$ J.C., Effects of inflammation-associated acute-phase response on hepatic and renal indices in the horse, Aust. Vet. J. 76 (1998) 187-194.

[114] Milne E.M., Doxey D.L., Kent J.E., Acute phase proteins in grass sickness (equine dysautonomia), Res. Vet. Sci. 50 (1991) 273 278.

[115] Mizuhara H., O`Neill E., Seki N., Ogawa T. Kusunoki C., Otsuka K., Satoh S., Niwa M., Senoh H., Fujiwara H., T cell activationassociated hepatic injury: Mediation by tumor necrosis factors and protection by Interleukin-6, J. Exp. Med. 179 (1994) 1529-1537.

[116] Mold C., Du Clos T.W., Nakayama S., Edwards K.M., Gewurz H., C-reactive protein reactivity with complement and effects on phagocytosis, in: Kushner I., Volankis J.E., Gewurz H. (Eds.), C-reactive protein and the plasma protein response to tissue injury, The New York Academy of Science 389, New York, 1982, pp. 251-262.

[117] Molenaar A., Rajan G., Pearson M., Miles M., Petrova R., Davis S., Stelwagen K., A serum amyloid protein homologue is expressed by the mammary gland in a similar pattern to lactoferrin, Proceedings of the 3rd European Colloquium on food safety and acute phase proteins, Doorn, The Netherlands, 2002. 
[118] Morimatsu M., Syoto B., Shimada N., Fujinaga T., Yamamoto S., Saito M., Naiki M., Isolation and characterization of bovine haptoglobin from acute phase sera, J. Biol. Chem. 266 (1991) 11833-11837.

[119] Morimatsu M., Sarikaputi M., Syotu B., Saito M., Yamamoto S., Naiki M., Bovine haptoglobin: single radial immunodiffusion assay of its polymeric forms and dramatic rise in acute-phase sera, Vet. Immunol. Immunopathol. 33 (1992) 365-372.

[120] Murata H., Miyamoto T., Bovine haptoglobin as a possible immunomodulator in the sera of transported calves, Br. Vet. J. 149 (1993) 277-283.

[121] Murtaugh M.P., Porcine cytokines, Vet. Immunol. Immunopathol. 43 (1994) 37-44.

[122] Murtaugh M.P., Baarsch M.J., Zhou Y., Scamurra R.W., Lin G., Inflammatory cytokines in animal health and disease, Vet. Immunol. Immunopathol. 54 (1996) 45-55.

[123] Myers M., Murtaugh M.P., Cytokines in animal health and disease, Marcel Dekker, New York, 1995.

[124] Nakagawa H., Yamamoto O., Oikawa S., Higushi H., Watanabe A., Katoh N., Detection of serum haptoglobin by enzyme-linked immunosorbent assay in cows with fatty liver, Res. Vet. Sci. 62 (1997) 137-141.

[125] Nakajima Y., Momotani E., Murakami T., Ishikawa Y., Morimatsu M., Saito M., Suzuki H., Yasukawa K., Induction of acute phase protein by recombinant human interleukin-6 (IL-6) in calves, Vet. Immunol. Immunopathol. 35 (1993) 385-391.

[126] Nakayama T., Sonada S., Urano T., Yamada T., Okada M., Monitoring both serum amyloid protein A and C-reactive protein as inflammatory markers in infectious diseases, Clin. Chem. 39 (1993) 293-297.

[127] Nawroth P.P., Bank I., Handley D., Cassimeris J., Chess L., Stern D., Tumor necrosis factor/cachectin interacts with endothelial cell receptors to induce release of interleukin 1, J. Exp. Med. 163 (1986) 1363-1375.

[128] Nunokawa Y., Fujinaga T., Taira T., Okumura M., Yamashita K., Tsunoda N., Hagio M., Evaluation of serum amyloid A protein as an acute-phase reactive protein in horses, J. Vet. Med. Sci. 55 (1993) 1011-1016.

[129] Oh S.-K., Pavlotsky N., Tauber A.I., Specific binding of haptoglobin to human neutrophils and its functional consequences, J. Leukoc. Biol. 47 (1990) 142-148.

[130] Ohtsuka H., Kudo K., Mori K., Nagai F., Hatsugaya A., Tajima M., Tamura K., Hoshi
F., Koiwa M., Kawamura S., Acute phase response in naturally occurring coliform mastitis, J. Vet. Med. Sci. 63 (2001) 675678.

[131] Okada M., Kitahara M., Kishimoto S., Matsuda T., Hirano T., Kishimoto T., IL-6/ BSF-2 functions as a killer helper factor in the in vitro induction of cytotoxic T cells, $\mathrm{J}$. Immunol. 141 (1988) 1543-1549.

[132] Pattinson R.C., Theron G.B., Inter-observer variation in symphysis-fundus measurement, S. Afr. Med. J. 76 (1989) 621-622.

[133] Pedersen L.H., Aalbæk B., Røntved C.M., Ingvartsen K.L., Sorensen N.S., Heegaard P.M.H., Jensen H.E., The initial pathogenesis and inflammatory response in experimental bovine mastitis due to Streptococcus uberis, J. Comp. Pathol. 128 (2003) 156164.

[134] Peltola H.O., C-reactive protein for rapid monitoring of infections of the central nervous system, Lancet (1982) 980-982.

[135] Pepys M.B., Baltz M.L., Acute phase proteins with special reference to C-reactive protein and related proteins (Pentaxins) and serum amyloid A protein, Adv. Immunol. 34 (1983) 141-212.

[136] Pepys M.B., Baltz M., Gomer K., Davies A.J.S., Doenhoff M., Serum amyloid P-component is an acute-phase reactant in the mouse, Nature 278 (1979) 259-261.

[137] Pepys M.B., Baltz M.L., Tennent G.A., Serum Amyloid A protein (SAA) in horses: objective measurement of the acute phase response, Equine Vet. J. 21 (1989) 106-109.

[138] Petersen H.H., Nielsen J.P., Jensen A.L., Heegaard P.M.H., Evaluation of an Enzyme Linked Immuno Sorbent Assay (ELISA) for Determination of Porcine Haptoglobin, J. Vet. Med. Ser. A 48 (2001) 513-523.

[139] Petersen H.H., Dideriksen D., Christiansen B.M., Nielsen J.P., Haptoglobin serum concentration as marker of clinical signs in finishing pigs, Vet. Rec. 151 (2002) 85-89.

[140] Petersen H.H., Ersbøll A.K., Jensen C.S., Nielsen J.P., Variation of serum haptoglobin concentration in slaughter pigs of different health status, Prev. Vet. Med. 54 (2002) 325-335.

[141] Petersen H.H., Enoe C., Nielsen E.O., Observer agreement on pen-level prevalence of clinical signs in finishing pigs (submitted).

[142] Polonovski M., Jayle M.-F., Peroxydases animales. Leur spécificité et leur role biologique, Bull. Soc. Chim. Biol. (1939) 66-91. 
[143] Pue C.A., Mortensen R.F., Marsh C.B., Pope H.A., Wewers M.D., Acute phase levels of C-reactive protein enhance IL-1 $\beta$ and IL-1ra production by human blood monocytes but inhibit IL-1 $\beta$ and IL-1ra production by alveolar macrophages, J. Immunol. 156 (1996) 1594-1600.

[144] Putnam F.W., Haptoglobin, in: Putnam F.W. (Ed.), The plasma proteins, Academic Press, 1975.

[145] Richter H., Haptoglobin bei Haussäugetieren, III. Mitteilung: Der Haptoglobingehalt im Blutplasma und -serum von Widerkaüern und Sweinen unter verschiedenen physiologischen Bedingungen, Arch. Exp. Vetmed. 28 (1974) 505-519.

[146] Richter H., Haptoglobin bei Haussäugstieren. IV. Mitteilung: Experimentelle Beeinflussung des Haptoglobinspiegels, Arch. Exp. Vetmed. 29 (1975) 217-230.

[147] Robey F.A., Jones K.D., Tanata T., Liu T.Y., Binding of C-reactive protein to chromatin and nucleosome core particles. A possible physiological role of C-reactive protein, J. Biol. Chem. 259 (1984) 7311-7316.

[148] Saini P.K., Webert D.W., Application of acute phase reactants during antemortem and postmortem meat inspection, J. Am. Vet. Med. Assoc. 198 (1991) 1898-1901.

[149] Saini P.K., Riaz M., Webert D.W., Eckersall P.D., Young C.R., Stanker L.H., Chakrabarti E., Judkins J.C., Development of a simple enzyme immunoassay for blood haptoglobin concentration in cattle and its application in improving food safety, Am. J. Vet. Res. 59 (1998) 1101-1107.

[150] Saklatvala J., Sarsfield S.J., Purification of pig IL-1 (Catabolin) and its ability to cause cartilage proteoglycan resorption, $\mathrm{Br}$. J. Rheumatol. 24 (1995) 47-51

[151] Salonen E.-M., Vaheri A., C-reactive protein in acute viral infections, J. Med. Virol. 8 (1981) 161-167.

[152] Salonen M., Hirvonen J., Pyörälä S., Sankari S., Sandholm M., Quantitative determination of bovine serum haptoglobin in experimentally induced Escherichia coli mastitis, Res. Vet. Sci. 60 (1996) 88-91.

[153] Saloniemi H., Use of somatic cell count in udder health work, in: Sandholm M., Honkanen-Buzalski T., Kaartinen L., Pyörälä S. (Eds.), The bovine udder and mastitis, University of Helsinki, Helsinki, Finland, ISBN 951-834-047-1, 1995, pp. 105-110.

[154] Satoh M., Fujinaga T., Okumora M., Hagio M., Sandwich enzyme-linked immunosorbent assay for quantitative measurement of serum amyloid A protein in horses, Am. J. Vet. Res. 56 (1995) 1286-1290.

[155] Sayers T.J., Wiltrout T.A., Bull C.A., Denn A.C., Pilaro A.M., Lokesh B., Effect of cytokines on polymorphonuclear neutrophil infiltration in the mouse, J. Immunol. 141 (1988) 1670-1677.

[156] Schijns V.E.C.J., Horzinek M.C., Cytokines in veterinary medicine, $\mathrm{CAB}$ International, Wallingford, 1997.

[157] Schindler R., Mancilla J., Endres S., Ghorbani R., Clark S.C., Dinarello C.A., Correlations and interactions in the production of Interleukin-6 (IL-6), IL-1 and Tumor Necrosis Factor (TNF) in human blood mononuclear cells: IL-6 suppresses IL-1 and TNF, Blood 75 (1990) 40-47.

[158] Sellmayer A., Limmert T., Hoffmann U., High sensitivity C-reactive protein in cardiovascular risk assessment - CRP mania or useful screening? Int. Angiol. 22 (2003) 15-23.

[159] Shainkin-Kestenbaum R., Berlyne G., Zimlichman S., Sorin H.R., Nyska M., Danon A., Acute phase protein, serum amyloid A, inhibits IL-1- and TNF-induced fever and hypothalamic $\mathrm{PGE}_{2}$ in mice, Scand. J. Immunol. 34 (1991) 179-183.

[160] Sheldon I.M., Noakes D.E., Rycroft A., Dobson H., Acute phase protein responses to uterine bacterial contamination in cattle after calving, Vet. Rec. 148 (2001) 172-175.

[161] Shim B.-S., Yoon C.S., Oh S.K., Lee T.H., Kang Y.-S., Studies on swine and canine serum haptoglobins, Biochim. Biophys. Acta 243 (1971) 126-136.

[162] Sipe J.D., Acute phase proteins in chronic inflammation, in: Koj A. (Ed.), The acute phase response to injury and infection, Elsevier, 1985, pp. 273-284.

[163] Skinner J.G., International standardization of acute phase proteins, Vet. Clin. Pathol. 30 (2001) 1-6.

[164] Skinner J.G., Brown R.A.L., Roberts L., Bovine haptoglobin response in clinically defined field conditions, Vet. Rec. 128 (1991) 147-149.

[165] Smith B.I., Donovan G.A., Risco C., Littell R., Young C., Stanker L.H., Elliott J., Comparison of various antibiotic treatments for cows diagnosed with toxic puerperal metritis, J. Dairy Sci. 81 (1998) 1555-1562.

[166] Smith B.I., Donovan G.A., Risco C., Young C., Stanker L.H., Serum haptoglobin concentrations in Holstein dairy cattle with toxic puerperal metritis, Vet. Rec. 142 (1998) 83-85. 
[167] Steel D.M., Whitehead A.S., The major acute phase reactants: C-reactive protein, serum amyloid $\mathrm{P}$ component and serum amyloid $\mathrm{A}$ protein, Immunol. Today 15 (1994) 81-88.

[168] Stoneham S.J., Palmer L., Cash R., Rossdale P.D., Measurement of serum amyloid A in the neonatal foal using a latex agglutination immunoturbidometric assay: determination of the normal range, variation with age and response to disease, Equine Vet. J. 33 (2001) 599-603.

[169] Straw B.E., Meuten D.J., Thacker B.J., Physical examination and diagnosis, in: Straw B.E., D'Allaire S.D., Mengeling W.L., Tailor D.J. (Eds.), Diseases of swine, 8(1), Blackwell Science Ltd., 1999, pp. 3-18.

[170] Suffredini A.F., Fantuzzi G., Badolato R., Oppenheim J.J., O’Grady N., New insights into the biology of the acute phase response, J. Clin. Immunol. 19 (1999) 203-214.

[171] Taira T., Fujinaga T., Okumura M., Yamashita K., Tsunoda N., Mizuno S., Equine haptoglobin: Isolation, characterization and the effects of ageing, delivery and inflammation on its serum concentration, J. Vet. Med. Sci. 54 (1992) 435-442.

[172] Takai Y., Wong G.G., Clark S.C., Burakoff S.J., Herrmann S.H., B cell stimulatory factor-2 is involved in the differentiation of cytotoxic T lymphocytes, J. Immunol. 140 (1988) 508-512.

[173] Takiguchi M., Fujinaga T., Naiki M., Mizuno S., Otomo K., Isolation, characterization and quantitative analysis of C-reactive protein from horses, Am. J. Vet. Res. 51 (1990) 1215-1220.

[174] Theodossi A., Knill-Jones R.P., Skene A., Lindberg G., Bjerregaard B., HolstChristensen J., Williams R., Inter-observer variation of symptoms and signs in jaundice, Liver 1 (1981) 21-32.

[175] Thymann M., Svensmark O., Masumba G., Broks $\varnothing$ H., Skibsby L.B., Haptoglobin subtype determination by isoelectric focusing in agarose gel: Application to paternity testing and presentation of a new alpha-variant, Electrophoresis 11 (1990) 61-64.

[176] Tilg H., Dinarello C.A., Wier J.W., IL-6 and Acute Phase Proteins: Anti-inflammatory and Immunosuppressive mediators, Immunol. Today 18 (1997) 428-432.

[177] Tillet W.S., Francis T., Serological reactions in pneumonia with a non-protein somatic fraction of Pneumococcus, J. Exp. Med. 52 (1930) 561-571.

[178] Touissant M.J.M., van Ederen A.M., Gruys E., Implication of clinical pathology in assessment of animal health and in anima production and meat inspection, Comp. Haematol. Int. 5 (1995) 149-157.

[179] Tyler J.W., Cullor J.S., Titers, tests and truisms: Rational interpretation of diagnostic serologic testing, J. Am. Vet. Med. Assoc. 194 (1989) 1550-1558.

[180] Uchida E., Katoh N., Takahashi K., Induction of serum haptoglobin by administration of ethionine to cows, J. Vet. Med. Sci. 55 (1993) 501-502.

[181] Vilcék J., Le J., Immunology of cytokines: An introduction, in: Thomson A.W. (Ed.), The Cytokine Handbook, Academic Press, 1991, pp. 1-17.

[182] Volanakis J.E., Complement activation by C-reactive protein complexes, in: Kushner I., Volanakis J.E., Gewurz H. (Eds.), C-reactive protein and the plasma protein response to tissue injury, The New York Academy of Science 389, New York, 1982, pp. 235-250.

[183] von Asmuth E.J.U., Leeuwenberg J.F.M., van der Linden C.J., Buurman W.A., Tumor Necrosis Factor-alpha induces neutrophilmediated injury of cultured human endothelial cells, Scand. J. Immunol. 34 (1991) $197-$ 206.

[184] Webel D.M., Finck B.N., Baker D.H., Johnson R.W., Time course of increased plasma cytokines, cortisol, and urea nitrogen in pigs following intraperitoneal injection of lipopolysaccharide, J. Anim. Sci. 75 (1997) 1514 1520.

[185] Werling D., Sutter F., Arnold M., Kun G., Tooten P.C.J., Gruys E., Kreuzer M., Langhans W., Characterisation of the acute phase response of heifers to a prolonged low dose infusion of lipopolysaccharide, Res. Vet. Sci. 61 (1996) 252-257.

[186] Whicher J.T., Dieppe P.A., Acute phase proteins, in: Thompson R.A. (Ed.), Clinics in immunology and allergy, Vol. 5(3), W.B. Saunders, London, 1985, pp. 425-446.

[187] Whicher J.T., Chambers R.E., Higginson J., Nashef L., Higgins P.G., Acute phase response of serum amyloid $\mathrm{A}$ protein and $\mathrm{C}$ reactive protein to the common cold and influenza, J. Clin. Pathol. 38 (1985) 312 316.

[188] Wittum T.E., Young C.R., Stanker L.H., Griffin D.D., Perino L.J., Littledike E.T., Haptoglobin response to clinical respiratory tract disease in feedlot cattle, Am. J. Vet. Res. 57 (1996) 646-649.

[189] Xu L., Badolato R., Murphy W.J., Longo D.L., Anver M., Hale S., Oppenheim J.J., 
Wang J.M., A novel biological function of serum amyloid A. Induction of T lymphocyte migration and adhesion, J. Immunol. 155 (1995) 1184-1190.

[190] Yamamoto M., Katoh N., Adachi Y., The presence of two low molecular mass proteins immunologically related to 14 kilodalton serum amyloid $\mathrm{A}$ in the lipoprotein fraction and their decreased serum concentrations in calves with experimentally induced pneumonia, J. Vet. Med. Sci. 60 (1998) 181-187.

[191] Yoo J.-Y., Desiderio S., Innate and acquired immunity intersect in a global view of the acute-phase response, Proc. Natl. Acad. Sci. USA 100 (2003) 1157-1162.

[192] Yoshino K., Katoh N., Takahashi K., Yuasa A., Purification of a protein from serum of cattle with hepatic lipidosis and identification of the protein as haptoglobin, Am. J. Vet. Res. 53 (1992) 951-956.
[193] Yoshino K., Katoh N., Takahashi K., Yuasa A., Possible involvement of protein kinase $\mathrm{C}$ with induction of haptoglobin in cows by treatment with dexamethasone and by starvation, Am. J. Vet. Res. 54 (1993) 689-694.

[194] Young C.R., Wittum T.E., Stanker L.H., Perino L.J., Griffin D.D., Littledike E.T., Serum haptoglobin concentrations in a population of feedlot cattle, Am. J. Vet. Res. 57 (1996) 138-141.

[195] Zimlichman S., Danon A., Nathan I., Mozes G., Shainkin-Kestenbaum R., Serum amyloid $\mathrm{A}$, an acute phase protein, inhibits platelet activation, J. Lab. Clin. Med. 116 (1990) $180-186$

[196] Zouki C., Beauchamp M., Baron C.M., Filep J.G., Prevention of in vitro neutrophil adhesion to endothelial cells through shedding of L-selectin by C-reactive protein and peptides derived from C-reactive protein, J. Clin. Investig. 100 (1997) 522-529. 